\title{
Astrocytes Decreased the Sensitivity of Glioblastoma Cells to Temozolomide and Bay 11-7082
}

\author{
Sadaf E. Pustchi, Naze G. Avci, Yasemin M. Akay and Metin Akay * \\ Department of Biomedical Engineering, University of Houston, Houston, TX 77204, USA; \\ sebrahi9@uh.edu (S.E.P.); ngavci@uh.edu (N.G.A.); ymakay@uh.edu (Y.M.A.) \\ * Correspondence: makay@uh.edu; Tel.: +1-832-842-8813
}

Received: 3 August 2020; Accepted: 24 September 2020; Published: 28 September 2020

\begin{abstract}
Glioblastoma multiforme (GBM) is the most common malignant type of astrocytic tumors. GBM patients have a poor prognosis with a median survival of approximately 15 months despite the "Stupp" Regimen and high tumor recurrence due to the tumor resistance to chemotherapy. In this study, we co-cultured GBM cells with human astrocytes in three-dimensional (3D) poly(ethylene glycol) dimethyl acrylate (PEGDA) microwells to mimic the tumor microenvironment. We treated 3D coand mono-cultured cells with Temozolomide (TMZ) and the nuclear factor- $\mathrm{kB}$ (NF- $\mathrm{kB}$ ) inhibitor Bay 11-7082 and investigated the combined effect of the drugs. We assessed the expressions of glial fibrillary acidic protein (GFAP) and vimentin that play a role in the tumor malignancy and activation of the astrocytes as well as Notch-1 and survivin that play a role in GBM malignancy after the drug treatment to understand how astrocytes induced GBM drug response. Our results showed that in the co-culture, astrocytes increased GBM survival and resistance after combined drug treatment compared to mono-cultures. These data restated the importance of 3D cell culture to mimic the tumor microenvironment for drug screening.
\end{abstract}

Keywords: 3D co-culture; glioblastoma; astrocytes; tumor microenvironment; PEGDA

\section{Introduction}

Glioblastoma multiforme (GBM), a grade IV tumor based on the WHO classification, is the most common malignant type of astrocytic tumors [1]. GBM patients usually have a median survival of approximately 15 months with the "Stupp" Regimen, consisting of 6 weeks of radiation with daily Temozolomide (TMZ) followed by 6 cycles of TMZ [2,3]. However, despite the modern therapies, GBM patients still have poor prognosis and high tumor recurrence due to the tumor resistance to chemotherapy [4,5]. TMZ, a DNA alkylating agent, is currently the most widely used and effective chemotherapeutic drug for GBM [6]. One of the important mechanisms of TMZ resistance is the increased activity of $\mathrm{O}_{6}$-methylguanine-DNA methyltransferase (MGMT), which can repair the TMZ-induced guanine damage in DNA lesions [7]. However, the underlying molecular mechanism of TMZ resistance is more complex than its dependence on MGMT expression [8]. Another mechanism that is associated with TMZ resistance in GBM is the excessive activation of Nuclear Factor- $\mathrm{kB}$ (NF- $\mathrm{kB}$ ) [9]. It was shown that NF- $\mathrm{KB}$ inhibitor Bay 11-7082 suppressed MGMT and promoted TMZ-induced cytotoxicity and apoptosis in U251 GBM cells [8]. This suggests that the combination of TMZ and Bay 11-7082 drugs have a combinatorial effect of inhibiting GBM growth [10].

The tumor microenvironment has a crucial role in cancer development, progression, and response to treatment [5]. The GBM microenvironment does not only contain tumor cells but also a mixture of diverse stromal cell types. Those include endothelial cells (EC), which constitute blood vessels, microglia contributing to resistance of antiangiogenic therapy, and an extra-cellular matrix consisting of a mix of collagen, proteoglycans, fibers, and astrocytes [11-14]. Astrocytes comprise $\sim 50 \%$ of 
all brain cells, support the neural network, promote cell-cell communications, and participate in the formation, development, and maintenance of neural circuits in the central nervous system (CNS) $[13,15,16]$. In malignant diseases of the CNS, reactive astrocytes can impact the course of the disease. Tumor-associated astrocytes promote tumor malignancy by causing cell proliferation and migration [16] and contribute to anti-inflammatory responses [17]. Reactive astrocytes are characterized by the upregulation of two cytoplasmic intermediate filament proteins (IF), glial fibrillary acidic protein (GFAP) and vimentin [15]. GFAP is the major protein involved in cell communication and provides mechanical support to cells and the functioning of the blood-brain barrier [18]. Vimentin is the major cytoskeletal component present in immature glia and a biomarker of cellular epithelial to mesenchymal transition (EMT). It is known to play a crucial role in the maintenance of cellular integrity and regulating GBM cell invasion and metastatic tumor spread $[19,20]$. Its expression has been reported in most of the glioma cell lines, such as U-118MG, U-373MG, and U-87MG [19]. Although vimentin has been used as a biomarker, its role in GBM has not been explored in detail. Notch-1 and survivin are associated with GBM apoptosis and proliferation in tumor microenvironment [21,22]. The Notch-1 signaling pathway regulates important biological processes such as cell proliferation, apoptosis, migration, self-renewal, and differentiation $[23,24]$. Notch-1 overexpression correlates with a high grade glioma and a poor prognosis, suggesting that upregulated Notch-1 signaling promotes a more undifferentiated and aggressive tumor phenotype [21,25]. Survivin is a member of the inhibitor-of-apoptosis (IAP) family and its overexpression suppresses cell death [24]. Its expression has been associated with enhancing malignant potential of gliomas [25]. Survivin expression has been reported as a risk factor for resistance to radiation and chemotherapy in GBM [26].

Traditionally, two-dimensional (2D) models are used to study drug treatments, wherein tumor cells are cultured as a monolayer and do not closely mimic the tumor physiological microenvironment [27]. Cancer cells grown on a flat 2D surface lose crucial signaling pathways which define natural responses of the cells' tumor growth, metabolism, and differentiation [28]. Moreover, significant differences have been shown in cell behavior, gene expression, and drug response when cells were cultured in three-dimensional (3D) compared with 2D monolayer culture [29,30]. In 2D cultures, cells promoting cell-to-cell and cell-to-matrix interactions and displaying a hypoxic core that is more resistant to chemotherapy, immunotherapy, and radiation therapy cannot be observed thoroughly [29]. Therefore, in drug screening, 2D cultures may not be the best representation of the in vivo tumor microenvironment. A simulation of the tumor microenvironment in a 3D culture model would give more precise information in addressing the challenges of drug response and resistance.

Several hydrogel microfabrication technologies have been used to develop biologically relevant 3D scaffolds, including photolithography, 3D bioprinting, and microfluidics [31-33]. Photolithography is one of the prominent techniques in 3D scaffold fabrication due to the simple and cost-efficient preparation process [31]. Photomask-based photolithography is a conventional type of photolithography to build a 3D scaffold which does not require a silicon mold or PDMS (polydimethylsiloxane) stamp [32]. This method has the advantages of cost-efficient preparation process, high reproducibility, and convenient control over the size and shape of the micropattern [33]. Hydrogels are one of the most common tissue engineering scaffolds due to their ability to maintain a precise 3D structure, contribute to the mechanical support of the cells, and simulate the extracellular matrix [34]. Poly(ethylene glycol) dimethyl acrylate (PEGDA) is used to fabricate 3D scaffolds with photolithography for its biocompatibility, ease of crosslinking to create a hydrogel, and finely tunable bioactivity [34].

In our lab, we used 3D GBM spheroid systems for several studies, including PEGDA hydrogel microwells, in order to understand the effect of the tumor microenvironment on GBM growth [33,35]. We also investigated the interaction of 3D GBM spheroids with endothelial cells [36]. In this study, we explored the interaction of 3D GBM spheroids with astrocytes before and after drug treatment. GBM cells were co-cultured with human astrocytes in PEGDA microwells. Then, they were treated with TMZ and/or NF-KB inhibitor (Bay 11-7082) to understand the effect of astrocytes 
in GBM growth and drug response. Furthermore, using real-time PCR (qPCR) and Western blot analysis, the expressions of proteins that play role in the activation of astrocytes, such GFAP and vimentin, as well as GBM malignancy, such as Notch-1 and survivin, were investigated in the drug-treated LN229-astrocyte co-culture and compared with the mono-cultures. Our data indicated that the presence of astrocytes increased cell viability and the expression of the proteins in the co-culture after the drug treatment compared with the mono-cultures. These results showed the importance of the tumor microenvironment in the GBM growth, proliferation, and drug resistance.

\section{Results}

\subsection{Microwell Preparation}

PEGDA microwells were fabricated as previously described [33,34], as shown in Figure 1a. Photoresponsive hydrogels are composed of a polymeric network and photoreactive moiety, which capture the optical signal and transfer it to the functional part of the polymers [37]. The hydrogel solution is exposed to UV light through a patterned photomask in the presence of a photoinitiator. Transparent regions of the photomask cause photoreaction, which leads to crosslinking in the polymer and forms hydrogel microwells [38]. The PEGDA microwell stability was due to 3-(Trimethoxysilyl) propyl methacrylate (TMSPMA) treatment on the cover glass surface, which provides covalent bonding between the glass surface and PEGDA hydrogel [39]. Fabricated microwells were able to maintain their stability without detaching from the cover glass for a total of 14 days, as we previously showed [33].

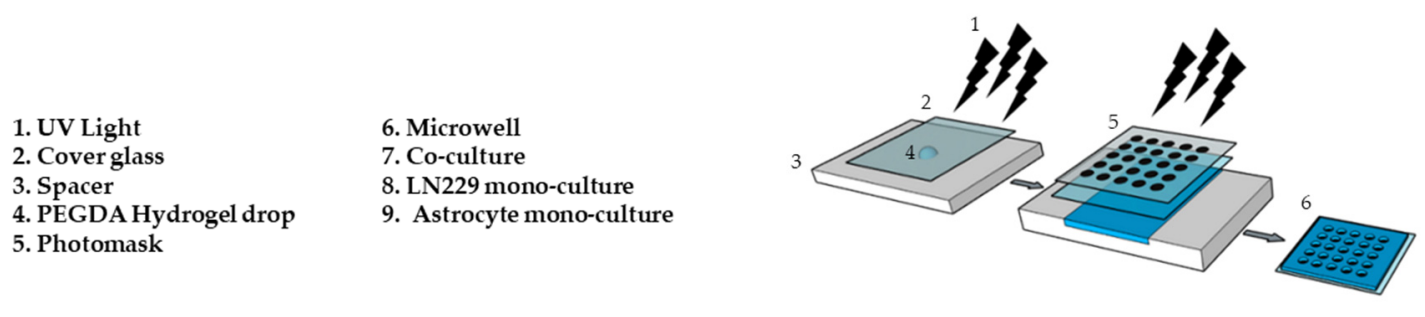

(a)

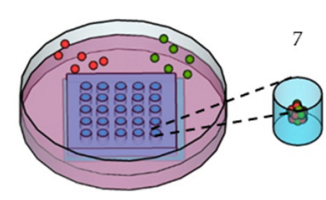

(b)

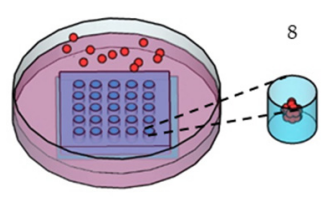

(c)

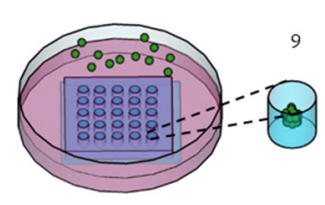

(d)

Figure 1. Preparation of the 3D cell culture in the (PEGDA) microwells. (a) Schematic of the PEGDA microwells' fabrication using a round pattern photomask (400 $\mu \mathrm{m}$ in diameter). (b) LN229 cells stained with a red cell tracker and astrocytes stained with a green cell tracker were added into the microwells and co-cultured with a ratio of 1:1 (LN229:astrocytes) for 7 days. (c) LN229 cells were mono-cultured into microwells for 7 days. (d) Astrocytes cells were mono-cultured into microwells for 7 days.

\subsection{Cell Culture and Drug Application}

For the first 7 days, we co-cultured LN229 cells and astrocytes with a ratio of 1:1 (Figure 1b), mono-cultured LN229 (Figure 1c), and astrocytes (Figure 1d) in the microwells to generate 3D spheroids. In this study, we used $600 \mu \mathrm{M}$ of TMZ and $10 \mu \mathrm{M}$ of Bay 11-7082 concentration on day 7 and cultured 3D spheroids for an additional 7 days since astrocytes have been found to be more TMZ resistant $[40,41]$.

The correlation between the cell seeding concentration and the size of the microwells has been previously optimized in our lab [33]. To evaluate the effect of astrocytes on GBM drug sensitivity, LN229 cells and astrocytes were co-cultured in the microwells with a concentration of $0.2 \times 10^{6}$ cells $/ \mathrm{mL}$ using a ratio of 1:1. In order to distinguish LN229 cells and astrocytes in the co-culture, LN299 cells were 
stained with a red cell tracker and astrocytes were stained with a green cell tracker. LN229 cells and astrocytes were mono-cultured separately with a concentration of $0.2 \times 10^{6}$ cells $/ \mathrm{mL}$ in the microwells. Using fluorescence microscopy, we observed that untreated groups in the LN229-astrocytes co-culture (Figure 2a), LN229 (Figure 2b), and astrocytes (Figure 2c) mono-cultures formed stable 3D spheroids after 7 days in the microwells.

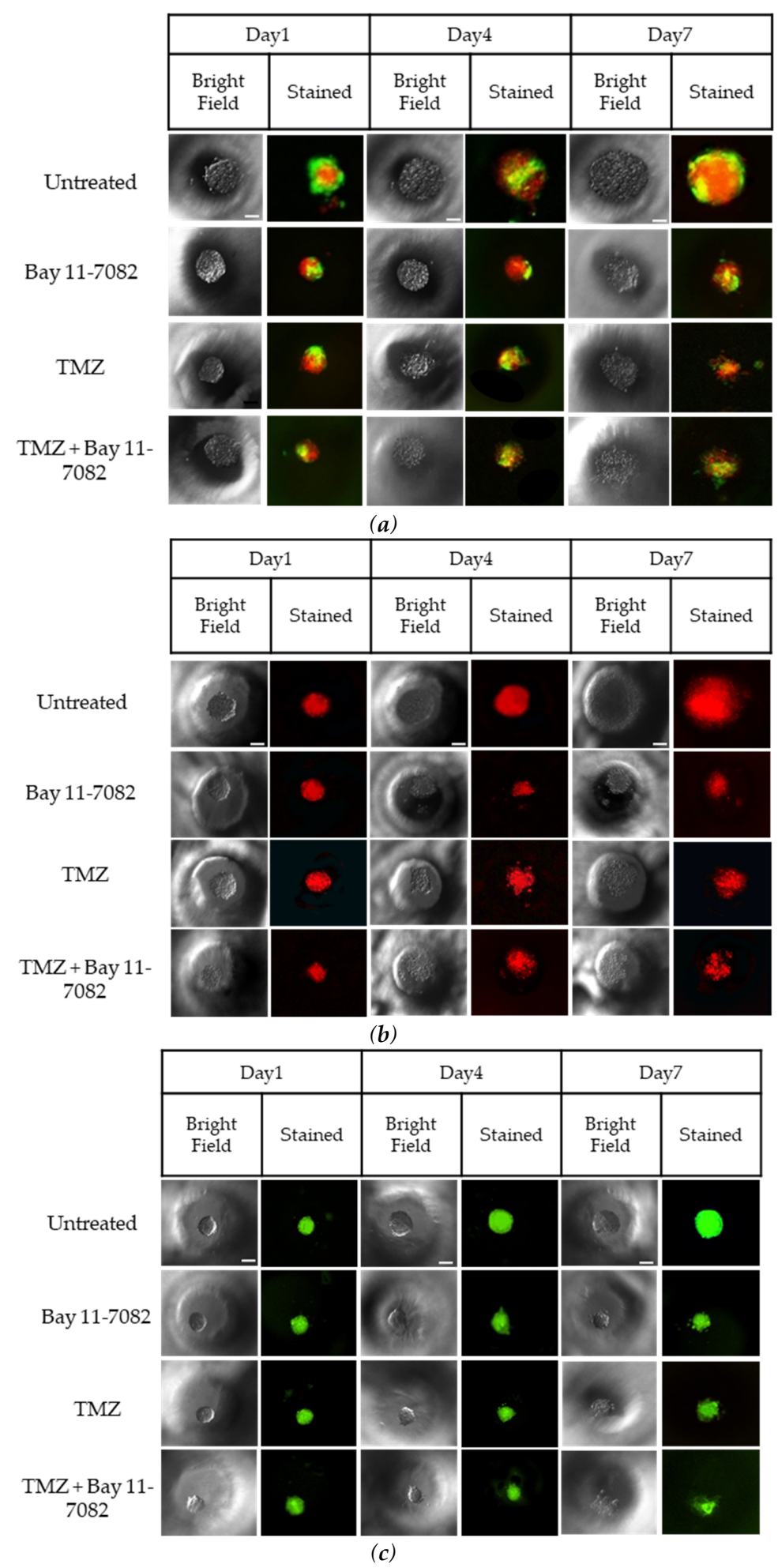

Figure 2. Cont. 

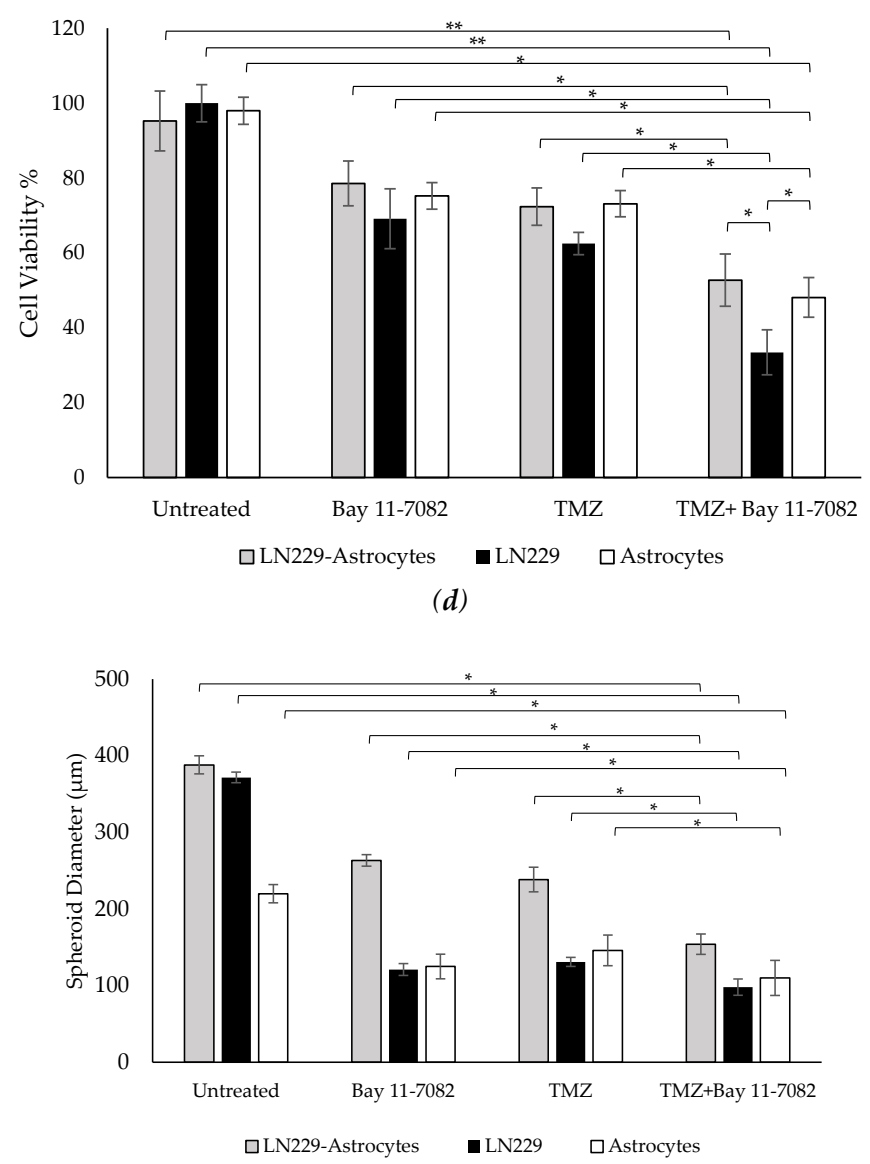

(e)

Figure 2. Representative images of co-cultured and mono-cultured cells in the PEGDA microwells $(400 \mu \mathrm{m})$ after 7 days of drug administrations: untreated, Bay 11-7082, Temozolomide (TMZ), and TMZ-Bay 11-7082. Effects of the drug treatment on both co-culture and mono-culture were visualized by the disaggregation of the dead cells on day 7. LN229 and astrocytes cells were stained with cell tracker red and cell tracker green, respectively. (a) LN229-astrocytes (1:1) co-culture. (b) LN229 mono-culture. (c) Astrocytes mono-culture. (d) Viability of co-cultured and mono-cultured cells. (e) Diameter of co-cultured and mono-cultured spheroids $(\mu \mathrm{m}) .{ }^{*}$ indicates $p<0.05$, ** indicates $p<0.01$. X20 objective. Scale bars, $100 \mu \mathrm{m}$.

Trypan blue cell viability assay was performed after the drug introduction to both co-cultured and mono-cultured cells on day 7 to understand the combined drug effect on the 3D spheroids. As shown in (Figure 2d), the drug treatment resulted in a decrease in the cell viability of co-cultured cells. On day 7 , the cell viability data of the co-cultured cells were $87.33 \pm 7.9 \%$ for the untreated group, $72 \pm 5.4 \%$ after Bay 11-7082, $66.33 \pm 5.7 \%$ after TMZ, and 48.28 $\pm 4.8 \%$ after TMZ-Bay 11-7082 treatment. The cell viability after TMZ-Bay 11-7082 treatment was significantly lower compared with the untreated group $(p<0.01)$. In addition, the cell viability significantly decreased after the combined drug treatment compared with both single-drug treatment groups $(p<0.05)$. The cell viability in the LN229 mono-culture after combined drug treatment was $30.66 \pm 5.2 \%$ and was significantly lower than the untreated group $(91.66 \pm 4.2 \%)(p<0.01)$. LN229 mono-cultured cells treated with Bay 11-7082 alone and TMZ alone showed $63.33 \pm 3.8 \%$ and $57.43 \pm 4.5 \%$ cell viability, respectively, and they were both significantly higher than combined drug treatment in mono-culture on day $7(p<0.05)$. The cell viability in astrocytes mono-culture after combined drug treatment was $48.09 \pm 5.29 \%$ and was significantly lower than the untreated group $98.0 \pm 3.62 \%(p<0.05)$. Astrocyte mono-culture treated with Bay 11-7082 alone and TMZ alone showed $75.23 \pm 3.51 \%$ and $73.14 \pm 3.62 \%$ cell viability, respectively, 
and they were both significantly higher than combined drug treatment in mono-culture on day 7 $(p<0.05)$. Our results also showed that the cell viability in LN229 significantly decreased compared with the co-culture and astrocyte mono-culture treated with combined drugs $(p<0.05)$. The cell viability data showed the combined treatment was more effective than using a single drug treatment, and it can be presumed that the presence of astrocytes in the co-culture significantly decreased drug effectiveness compared to mono-culture.

The size of the spheroids in the co-culture and mono-cultures on day 7 after drug administration was measured using Image (Figure 2e). The results showed that the size of the spheroids in the co-culture was $388 \mu \mathrm{m}$ in the untreated group, $263.33 \mu \mathrm{m}$ after Bay 11-7082, $238.3 \mu \mathrm{m}$ after TMZ, and $154 \mu \mathrm{m}$ after TMZ-Bay 11-7082 treatments. There was a significant decrease in the spheroid size of the co-culture after combined drug treatment compared with the untreated group $(p<0.05)$. Mono-culture LN229 spheroid size was $371.66 \mu \mathrm{m}$ in the untreated group, $121 \mu \mathrm{m}$ after Bay 11-7082, $134 \mu \mathrm{m}$ after TMZ, $98.1 \mu \mathrm{m}$ after TMZ-Bay 11-7082 treatments, and there was a significant decrease in the spheroid size of the mono-culture after combined drug treatment compared with the untreated group $(p<0.05)$. Spheroid sizes in the astrocytes mono-culture were $220 \mu \mathrm{m}$ in the untreated group, $125 \mu \mathrm{m}$ after Bay 11-7082, $146 \mu \mathrm{m}$ after TMZ, and $110 \mu \mathrm{m}$ after TMZ-Bay 11-7082 treatments. The decrease in the spheroid size of the astrocyte mono-culture after TMZ-Bay 11-7082 treatment was significant compared to the respective untreated group $(p<0.05)$.

In addition to cell viability assay, we further investigated how drugs affect the cell apoptosis. Therefore, we performed TUNEL assay. Co-cultured and mono-cultured cells were treated with or without TMZ and Bay 11-7082 and subjected to TUNEL assay to detect DNA damage (Figure 3a-c). The results showed that TUNEL $(+)$ cells in the co-treatment in the co-culture were increased 4.5-fold compared with the untreated and 1.71- and 1.44-fold compared with TMZ alone and Bay 11-7082 alone, respectively $(p<0.01)(p<0.05)$ (Figure 3d). TUNEL $(+)$ cells in the co-treatment in the LN229 mono-culture were increased 7.42-fold compared with the untreated $(p<0.01)$ and 2.16- and 1.67-fold compared with TMZ alone and Bay 11-7082 alone (Figure 3d). TUNEL $(+)$ cells in the co-treatment in the astrocytes mono-culture were increased 4.77-fold compared with the untreated $(p<0.01)$ and 2.15and 1.38-fold compared with TMZ alone and Bay 11-7082 alone (Figure 3c).

\subsection{Gene Expression Studies}

The molecular characterization and the interaction of GBM cells with astrocytes were investigated after the drug treatment. Gene expression studies were carried out using the co-culture and mono-culture spheroids treated with TMZ and/or Bay 11-7082. 3D spheroids in mono-culture without drug treatment were used as a control. Our results indicated that after the combined drug treatment, gene expressions of GFAP, vimentin, Notch-1, and survivin were significantly downregulated by $0.24-$, $1-, 1.5-$, and 0.23 -fold, respectively, in the co-culture, $0.06-, 0.14-, 0.13-$, and 0.07 -fold, respectively, in the LN229 mono-culture $(p<0.01)$, and $0.13,0.6,0.14$, and 0.15 in the astrocyte mono-culture $(p<0.05)$ (Figure 4a-d).

When co-cultured cells were treated with Bay 11-7082 alone, GFAP expression was significantly changed by 0.28 -fold $(p<0.01)$ and expressions of vimentin, Notch-1, and survivin genes were significantly higher $(0.5-, 0.62-$, and 0.31 -fold, respectively $(p<0.05))$, compared with the combined drug treatment. When co-cultured cells were treated with TMZ alone, the expressions of GFAP, vimentin, notch-1, and survivin were changed by 0.40-, 0.71-, 0.57-, and 0.23-fold, respectively, compared with the combined drug treatment $(p<0.05)$. When mono-cultured LN229 cells were treated with Bay 11-7082 alone and TMZ alone, the expressions of GFAP, vimentin, Notch1, survivin were changed by $0.17-, 0.45-, 0.40-, 0.18$-fold and $0.22-, 0.60-, 0.56-, 0.23$-fold, respectively, compared to combined drug treatment $(p<0.05)$. When mono-cultured astrocytes were treated with Bay 11-7082 alone and TMZ alone, the expressions of GFAP, vimentin, Notch-1, and survivin were changed by 0.18-, 0.46-, $0.5-, 0.35$-fold and 0.24-, 0.54-, 0.51-, 0.31-fold, respectively, compared to combined drug treatment. Expressions of vimentin, Notch-1, and survivin were significantly downregulated in both co- and 
mono-cultures after TMZ alone compared with the combined drug treatment. These results showed that combined drug treatment had more impact on the down-regulation of the GFAP and vimentin proteins that play role in the astrogliosis as well as survivin and Notch-1 that promote the tumor malignancy in the co-culture compared with the mono-cultures. These data suggested enhanced combinatorial effect of TMZ and Bay 11-7082 on the LN229-astrocytes co-culture.

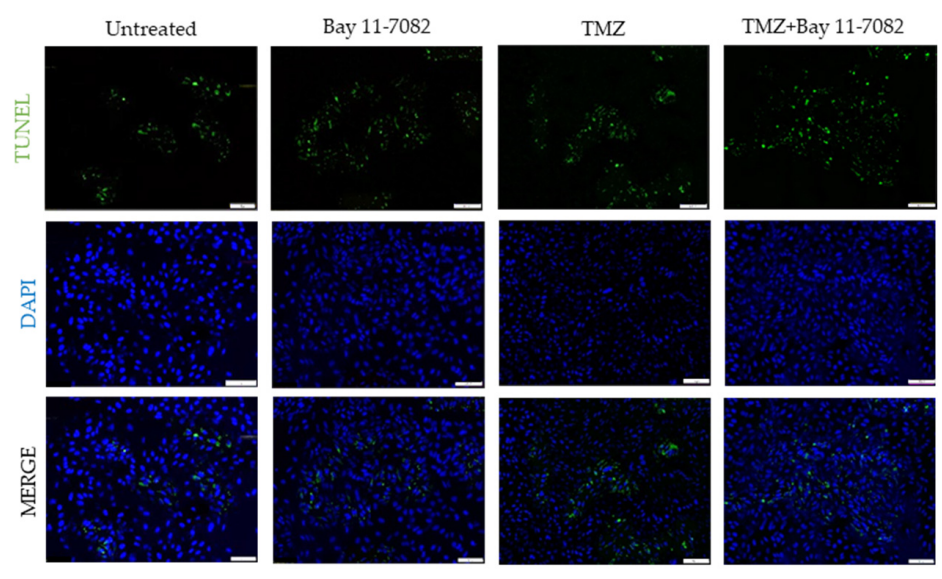

LN229-Astroctyes

(a)

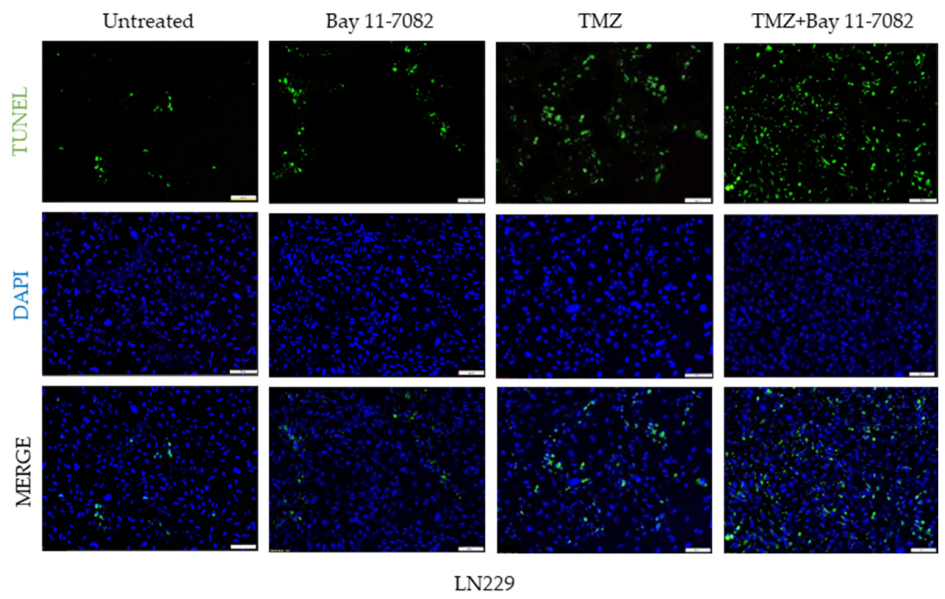

(b)

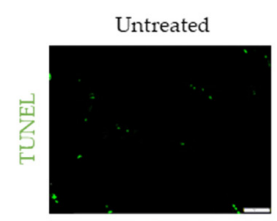

Bay 11-7082
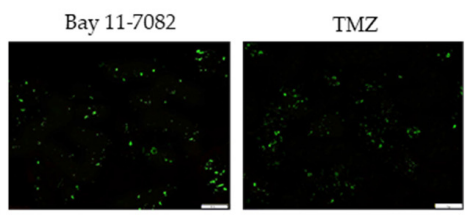

TMZ+Bay 11-7082
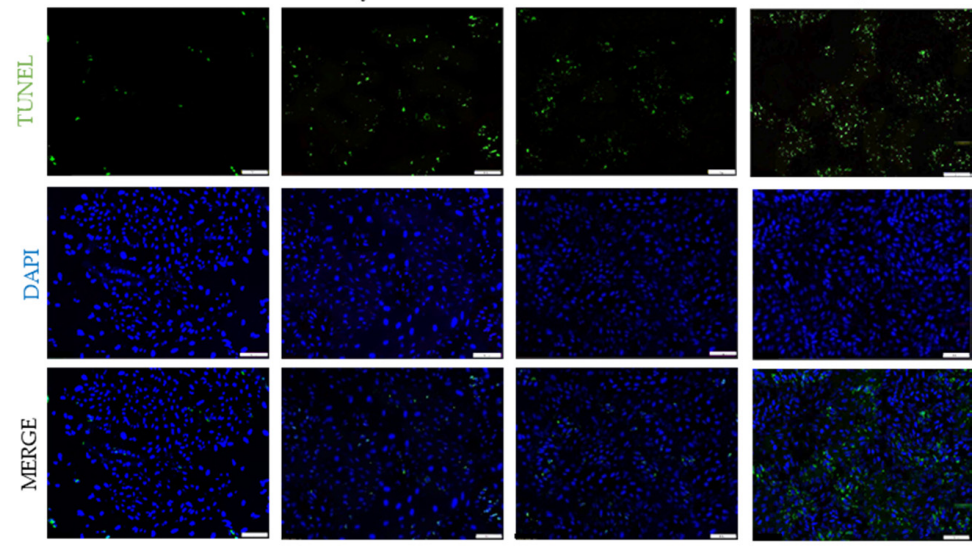

Astrocytes

(c)

Figure 3. Cont. 


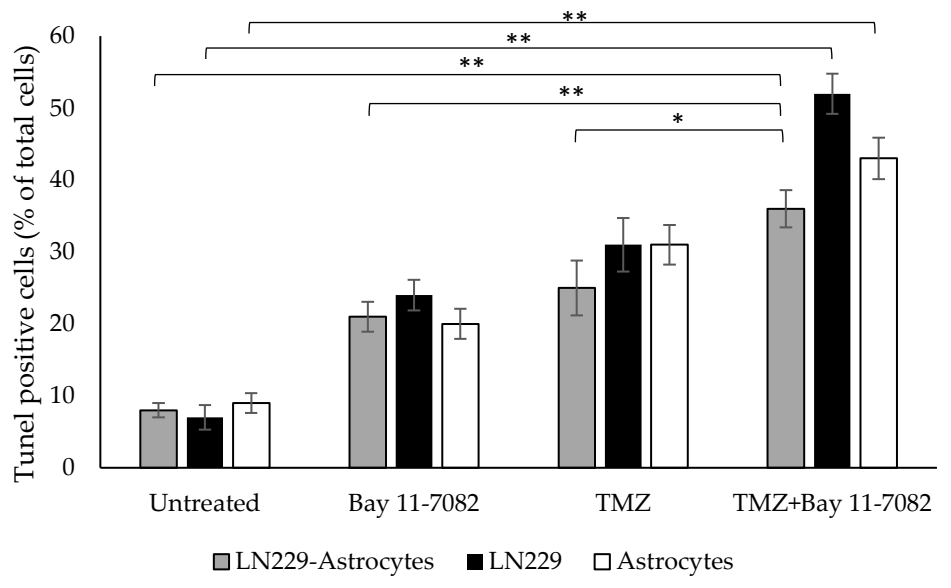

(d)

Figure 3. Fluorescent images of TUNEL (+) cells (green) in co-cultured and mono-cultured cells. (a) LN229-astrocytes co-culture. (b) LN229 mono-culture. (c) Astrocytes mono-culture. TUNEL assay was performed on cells treated with TMZ and/or Bay 11-7082 in the microwells. Cells were collected from the microwells, trypsinized, and re-plated into 8-well chamber slides. Nuclei were counterstained with DAPI (blue). (d) Numbers of TUNEL $(+)$ cells are presented as mean \pm SD of three biological replicates. * indicates $p<0.05,{ }^{* *}$ indicates $p<0.01$. X20 objective. Scale bars, $100 \mu \mathrm{m}$.

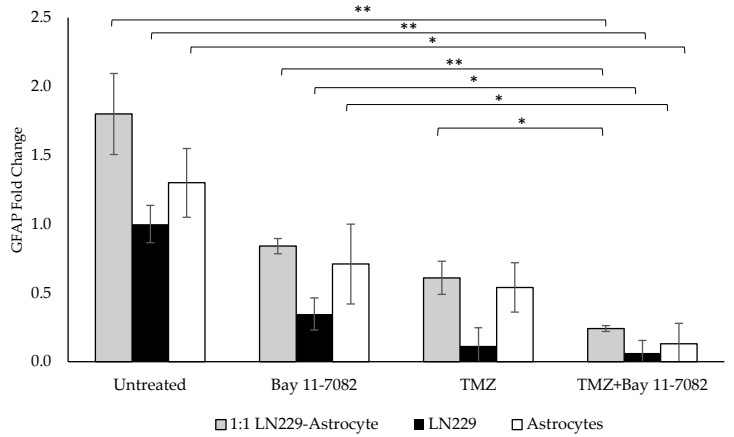

(a)

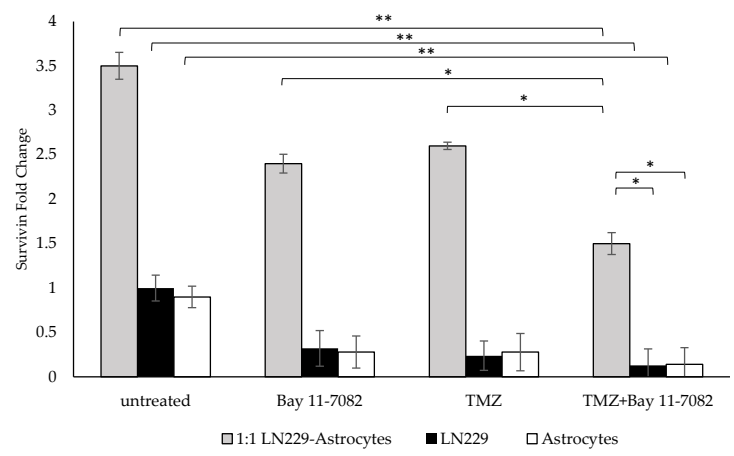

(c)

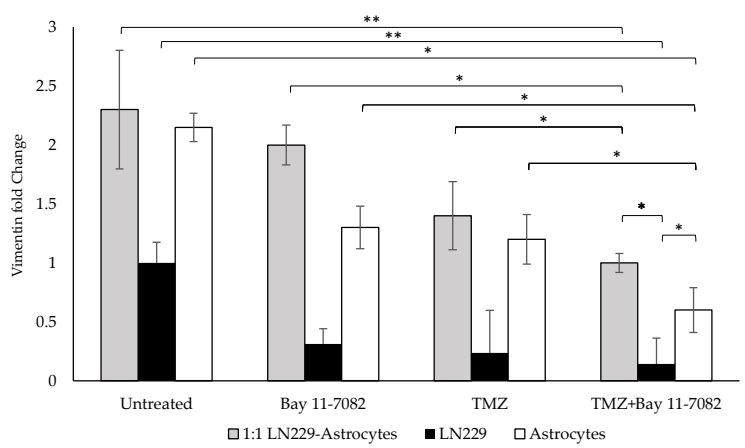

(b)

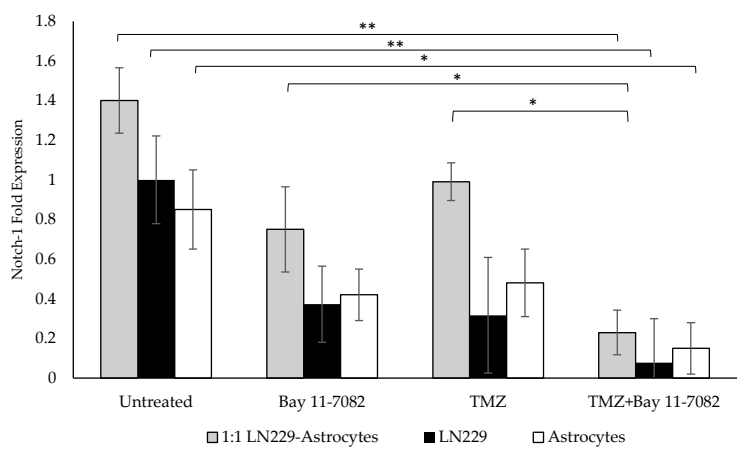

(d)

Figure 4. Gene expression analysis. Fold changes of (a) glial fibrillary acidic protein (GFAP), (b) vimentin, (c) Notch-1, and (d) survivin genes in the co-culture and mono-cultures. LN229 cells and astrocytes were treated with or without drugs for 7 days. Results were normalized to GAPDH total RNA level. Data represent the mean $\pm \mathrm{SD}$ of three biological replicates. ${ }^{*}$ indicates $p<0.05,{ }^{* *}$ indicates $p<0.01$. 


\subsection{Western Blot}

We performed Western blotting to analyze the expressions of GFAP, vimentin, Notch-1, and survivin proteins in the TMZ and/or Bay 11-7082 treated co-cultured and mono-cultured cells (Figure 5a-g). $3 \mathrm{D}$ spheroids in the mono-culture without drug treatment were used as the control group and all protein levels were normalized to $\beta$-actin housekeeping gene.

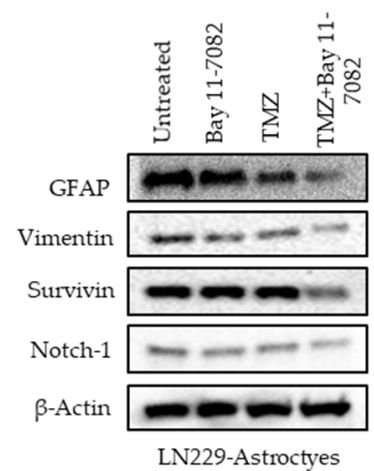

(a)

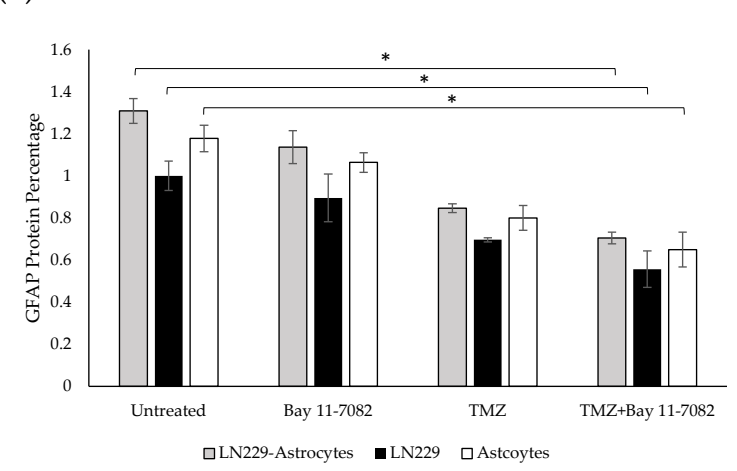

(d)

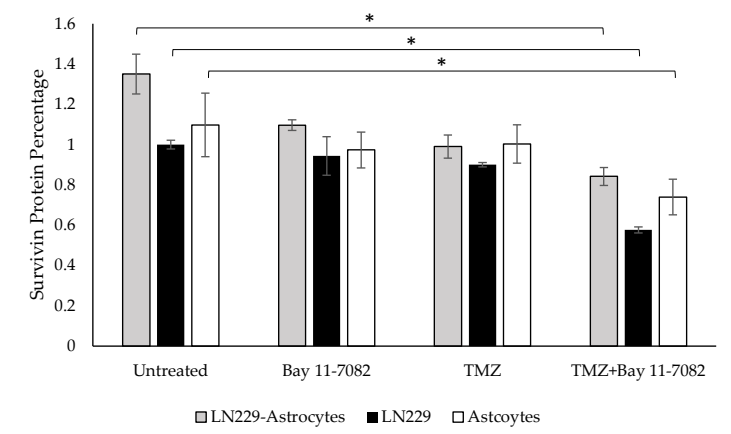

(f)

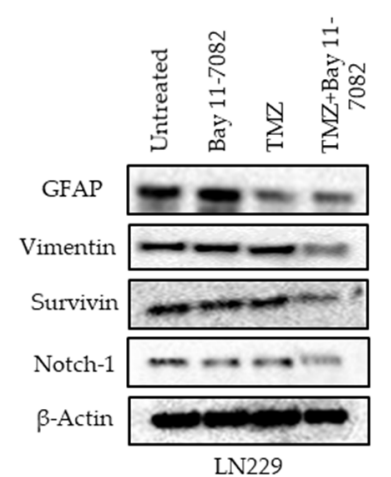

LN229

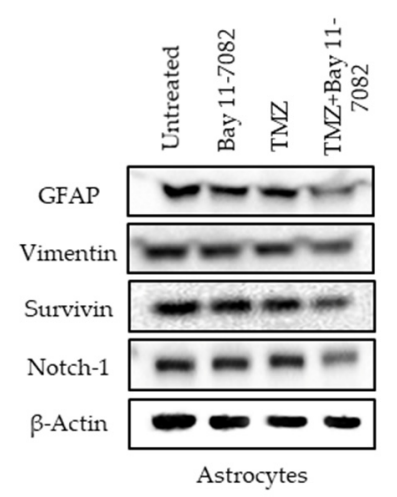

(c)

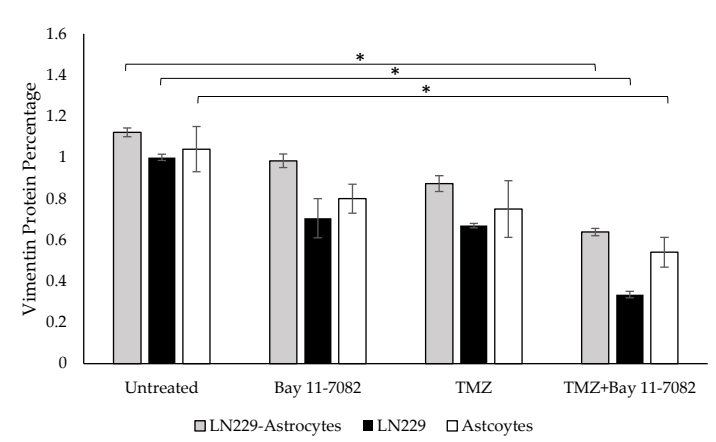

(e)

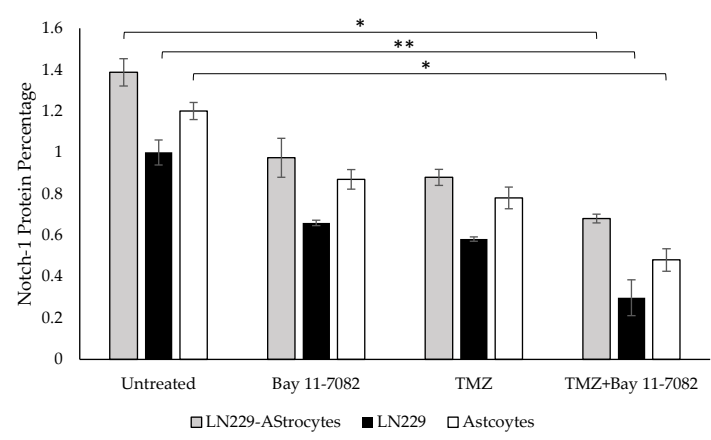

(g)

Figure 5. Western blot images of GFAP, vimentin, survivin, and Notch-1 in (a) co-culture and (b) LN229 mono-culture and (c) astrocytes mono-culture treated with or without drugs for 7 days. (d) Quantification of the fold change of GFAP protein. (e) Quantification of the fold change of vimentin protein. (f) Quantification of the fold change of survivin protein. (g) Quantification of the fold change of Notch-1 protein. The levels of the proteins were quantified using ImageJ. Data were normalized to $\beta$-Actin. Data represent the mean \pm SD of three biological replicates. * indicates $p<0.05$, ** indicates $p<0.01$.

The band intensities of GFAP, vimentin, Notch-1, and survivin proteins after combined drug treatment were determined as $0.70,0.63,0.68$, and 0.84 , respectively, in the co-culture and, 1.30, 1.12, 
$1.38,1.34$, respectively, in the untreated group of the co-cultured cells. These results showed that after combined drug treatment, GFAP, vimentin, Notch-1, and survivin expressions in the co-culture were significantly downregulated compared with untreated LN229 mono-culture group $(p<0.05)$. In the LN229 mono-culture, the band intensities of GFAP, vimentin, Notch-1, and survivin proteins after combined drug treatment were $0.55,0.33,0.29$, and 0.57 , respectively. In the astrocyte mono-culture, the band intensities of GFAP, vimentin, Notch-1, and survivin proteins after combined drug treatment were $0.91,0.86,0.74$ and 0.88 , respectively. The results showed that after combined drug treatment, GFAP, vimentin, survivin expressions $(p<0.05)$, and Notch-1 $(p<0.01)$ were significantly downregulated compared with the mono-cultured untreated groups.

\section{Discussion}

The current standard of care for GBM is maximum surgical resection combined with radiation and TMZ therapy. However, TMZ resistance is responsible for GBM tumor recurrences in most patients [33]. Therefore, there have been several attempts using combined drug treatment to develop new strategies for GBM treatment. Among the signaling pathways in GBM, NF- $\mathrm{kB}$ activation play an important role in promoting tumor pathobiology and response to therapy [42,43]. NF- $\mathrm{kB}$ is a multi-subunit transcription factor consisting of p50 (NF-kB1, p105), p52 (NF-kB2, p100), p65 (relA), and relB. These proteins exist as homo- and hetero-dimers with the most abundant form being p50/p65, and they are activated by multiple interrelated pathways. Some studies have also reported their expression in activated microglia [44]. Astrocytes are the most diverse glial cells in the CNS and are responsible for promoting GBM development. Interaction and communication between astrocytes and GBM cells via gap junction leads to increased intercellular calcium and resistance to chemotherapy [42]. Several pathways are involved in the interaction of GBM with astrocytes, such as NF-KB signaling pathway which regulates astrocyte formation in GBM tumor microenvironment [45]. Although several studies have shown that NF- $\mathrm{kB}$ signaling in astrocytes can contribute to pro-inflammatory responses following injury [46], there is still a lack of understanding of the effect of NF- $\mathrm{KB}$ on GBM tumor microenvironment and its interaction with TMZ.

A poor clinical outcome of chemotherapy can be attributed to the usage of 2D monolayer cultures as the initial drug screening method that frequently produces inaccurate results and does not predict chemoresistance [47]. 3D tumor models have the ability to mimic tumor microenvironment and provide more accurate toxicity information for modeling drug and radiation responses $[48,49]$. It has been shown that cells cultured in the 3D model show significant effects on clonogenic survival in patient-derived GBM [49] and were more resistant to TMZ compared to the 2D model, and this resistance was potentiated by hypoxia [50]. These data restated the similarity of 3D cultures to in vivo TMZ resistance. To understand the impact of astrocytes on GBM cell response to drug treatment, we established a 3D co-culture model using LN229 cells and astrocytes. In addition, to assess whether the astrocytic activation was due to GBM cells, we cultured astrocytes and LN229 alone in the microwells. We assessed the response of these co-cultured and mono-cultured cells to two different drugs, TMZ and NF-kB inhibitor Bay 11-7082. The cell viability assay showed a decrease in both co-cultured and mono-cultured cells on day 7 after TMZ and/or Bay 11-7082 administration. However, the co-cultured cells were more resistant to the combined drug treatment compared to both mono-cultures. The size of the spheroids showed a similar pattern, which showed bigger spheroids in the co-culture after combined drug treatment compared to both mono-cultured cells. We also performed TUNEL apoptosis assay to support our cell viability assay. These data showed significantly less apoptotic cells in the co-culture after combined drug treatment compared to both mono-cultures and more dead cells after combined drug treatment in the LN229 mono-culture compared to the co-cultured cells. Thus, we concluded that the combined drug treatment was more effective on the cells compared with the single drug administration, and the reactive astrocytes in the co-culture might have increased the drug sensitivity of the GBM cells to both drugs. 
Reactive astrocytes protect GBM cells from TMZ and Bay 11- 7082-induced apoptosis and have been shown to suppress the expression of MGMT in TMZ resistant GBM cell lines [8]. Therefore, we hypothesized that TMZ-Bay 11-7082 treatment can reduce astrocyte transformation and thus affect the expression of the proteins playing role in the tumor development and malignancy in the GBM-astrocyte co-culture. We investigated the expressions of several important markers in GBM development. GFAP is one of the most common markers in astrocyte differentiation and GBM development. Our findings first showed that GFAP was expressed in both co-culture and mono-culture. Vimentin, along with GFAP, is present in mature astrocytes as well as in LN229 cells [51]. Although vimentin is the major cytoskeletal component present in immature glia, it is expressed to the same extent in all grades of astrocytic tumors and correlated with the malignancy grade in gliomas [52]. Our qPCR showed that the expressions of both GFAP and vimentin genes in the co-culture were higher compared with the mono-culture for all treatment groups. This result confirmed the presence of reactive astrocytes in our 3D co-culture model. When we applied combined drug treatment, the expression of both GFAP and vimentin significantly decreased compared with both single drug treatment groups. This result implied that when TMZ was applied with Bay 11-7082, it showed more effect on the signaling pathways of GBM tumor than the single drug treatment. Western blot results confirmed that the downregulation in these genes was translated into protein expression. We observed significantly decreased expressions of GFAP and vimentin in the co-culture after TMZ- Bay 11-7082 treatment compared with the single drug treatment. The expression of these two markers pointed towards astrocytic lineage in the GBM cells [19]. Altogether, these results might imply that reactive astrocytes promoted GBM cells viability in the co-culture [53].

This astrocytic protection could be via gap junction communication (GJC) and the upregulation in the expression levels of malignancy genes such as Notch-1 and survivin [54]. Compared with the GBM mono-culture, reactive astrocytes promoted the upregulation of GFAP and vimentin proteins in the tumor microenvironment and possibly formed a functional barrier called a glial scar, thus increasing GBM chemoresistance [55], that needs to be further investigated. Notch-1 signaling is an evolutionarily conserved pathway that regulates cellular interactions and processes. Previous studies have shown that Notch-1 is upregulated in many glioma cell lines and primary human gliomas by promoting cell survival, proliferation, and invasion [56,57]. It has also been shown that several pathways including NF- $\mathrm{kB}$ can promote Notch-1 signaling, where NF- $\mathrm{kB}$ subunit $\mathrm{p} 65$ binds to the Notch-1 promoter and activates it [58]. Considering the importance of Notch-1 signaling in glioblastoma development, Notch-1-antagonizing strategies may hold great promise for therapeutic approaches. Although reactive astrocytes potentially increased the resistance of the co-culture to the drug treatment, our GBM-astrocyte co-culture treated with the combination of TMZ- Bay 11-7082 showed a significant decrease in both Notch-1 gene and protein expressions compared to the untreated group as well as the single drug treatments. These data suggest that the combined drug treatment could target Notch-1 signaling and, thus, the proliferation and Notch-1-dependent apoptosis-regulating pathway characterized in GBM [56]. Survivin is a member of the inhibitor-of-apoptosis (IAP) family [57]. Survivin expression has been found to be undetectable in normal adult tissues [59]. However, its expression has been reported in different tumor types including colorectal, breast, and ovarian [60,61]. Its prognostic value has also been investigated in gliomas [62]. Survivin expression in astrocytic tumors has been shown to vary with tumor malignancy $[22,63]$. However, its interaction with the tumor progression and resistance to drugs remain unclear. NF- $\mathrm{kB}$, which is considered as a pro-survival factor, promotes cell survival and proliferation. Proteins induced by NF- $\mathrm{KB}$ in GBM that act in this manner include Bcl-2, Bcl-xl, and the inhibitor of apoptosis proteins (IAPs) such as survivin. We have already shown in our lab that Bay 11-7082 in combination with TMZ modulated anti-apoptotic protein Bcl-2 and pro-apoptotic protein Bax in the NF- $\mathrm{kB}$ signaling pathway in 3D patient-derived GBM cells [64]. In this study, we further investigated the effect of the combined drug treatment on the survivin expression. As we discussed in the previous paragraphs, reactive astrocytes increased the resistance of the co-culture to the drug treatment compared with mono-cultures, and survivin expression was higher in the 
co-culture than the mono-cultures. However, we observed a significant decrease in the survivin gene expression compared with the untreated group as well as the single drug treatments. This result suggested that survivin expression was positively and significantly associated with GBM proliferation and susceptibility to drugs.

As a summary, in this study, we investigated the efficacy of 3D LN229 GBM cells-astrocyte co-culture model to mimic the tumor microenvironment and modulate the sensitivity of GBM cells to combined TMZ and NF- $\mathrm{kB}$ inhibitor Bay 11-7082 treatment. Our results suggested that TMZ in combination with NF- $\mathrm{kB}$ inhibitor Bay 11-7082 increased GBM survival and resistance. However, considering that LN229 is a commercial non-stem GBM cell line $[65,66]$, future studies should investigate the sensitivity of the astrocyte co-culture model with other GBM cell lines, including T98G, U251, U87 [66] and patient-derived primary GBM cell lines with or without stem cells [67], to TMZ in combination with NF-kB inhibitor Bay 11-7082 or different drug combinations.

\section{Materials and Methods}

\subsection{Cell Lines and Cell Culture}

Glioblastoma LN229 cell line was purchased from the American Tissue Culture Collection (ATCC, Manassas, VA, USA). LN229 cells were cultured in Dulbecco's modified Eagle's medium (DMEM) (Corning, New York, NY, USA) supplemented with 10\% $(v / v)$ fetal bovine serum (FBS) (VWR, Dallas, TX, USA) and $1 \%(v / v)$ penicillin/streptomycin (VWR, Dallas, TX, USA). Primary human astrocytes were obtained from ScienCell (Carlsbad, CA, USA). They were cultured in the basal medium supplemented with $2 \%(v / v)$ fetal bovine serum, $1 \%(v / v)$ astrocyte growth supplement, and penicillin/streptomycin. All cells were maintained under sterile tissue culture hoods and kept in a 95\% air-5\% CO2 humidified incubator at $37^{\circ} \mathrm{C}$.

\subsection{Microwell Fabrication}

Microwell fabrication process was followed as described previously [33]. Briefly, $25 \times 25 \mathrm{~mm}$ cover glass slides were washed and treated with 3-(Trimethoxysilyl) propyl methacrylate 98\% (TMSPMA) (Life Technologies, New York, NY, USA). Then, the treated slide was covered with $20 \mu \mathrm{L}$ of $40 \%$ $(w / w)$ PEGDA (MW 700) (Life Technologies, New York, NY, USA) solution containing $0.2 \%(w / v)$ of the photoinitiator (PI) 2-hydroxy-2-methyl propiophenone dissolved in Phosphate Buffered Saline (PBS) (Life Technologies, New York, NY, USA). The glass slide was exposed to Lumen Dynamics the OmniCure ${ }^{\circledR}$ Series 2000 (Lumen Dynamics Group Inc, Mississauga, ON, Canada) for $30 \mathrm{~s}$ at a working distance of 6 inches. At the end, $300 \mu \mathrm{L}$ of prepared PEGDA solution was added to the slide and exposed to UV light for $36 \mathrm{~s}$ with the desired photomask on top of it. The photomask was purchased from (CADart, Bandon, OR, USA) and designed in round pattern of $400 \mu \mathrm{m}$ in diameter with AutoCAD (Autodesk Inc, San Rafael, CA, USA).

\subsection{Co-Culture of Glioblastoma Cells and Astrocyte}

LN229 cells and astrocytes were first cultured in the cell culture plates until they reached their confluency. Then, they were trypsinized and plated in microwells with a density of $0.2 \times 10^{6}$ cells $/ \mathrm{mL}$ and a ratio of 1:1 (GBM:Astrocytes) and cultured in the astrocyte medium. Astrocytes used for this experiment were between passages 2 and 4 . The same number of the cells were used for both mono-culture and co-culture. LN229 cells were stained with $10 \mu \mathrm{M}$ of CellTracker Red CMTPX fluorescence dye (Thermo Fisher Scientific, Houston, TX, USA) and astrocytes were stained with $10 \mu \mathrm{M}$ of CellTracker Green CMFDA fluorescence dye (Thermo Fisher Scientific, Houston, TX, USA) in order to distinguish between two cell lines. LN229 cells and astrocytes were mono-cultured with a density of $0.2 \times 10^{6}$ cells $/ \mathrm{mL}$ and kept in the same culture condition. Cell spheroid formation inside of the microwell was monitored using an Olympus fluorescence microscope (Olympus, Tokyo, Japan) 


\subsection{Drug Administration}

After 7 days of spheroid culture in the microwells, TMZ and/or Bay 11-7082 were introduced to the cells in the microwells. TMZ (Thermo Fisher Scientific, Houston, TX, USA) was dissolved in dimethylsulfoxide (DMSO) (Santa Cruz Biotechnology, Dallas, TX, USA) to prepare a solution of $10 \mathrm{mM}$ TMZ. The solution was diluted to $600 \mu \mathrm{M}$ TMZ in astrocyte media. Bay 11-7082 was dissolved in DMSO and diluted to $10 \mu \mathrm{M}$ using appropriate media [11]. Cell culture media was removed from the microwells and replaced with $600 \mu \mathrm{M}$ TMZ and/or $10 \mu \mathrm{M}$ Bay 11-7082 for the co-culture and mono-cultures. Then, the spheroids were cultured in the microwells for 7 more days. Untreated microwells were maintained under the same conditions.

\subsection{In Situ Apoptosis Assay (TUNEL)}

LN229 cells and astrocytes, co- or mono-cultured in the microwells, were treated with TMZ and/or Bay 11-7082 for 7 days. They were collected from the microwells and trypsinized to assess DNA fragmentation with TACS ${ }^{\circledR} 2$ TdT-Fluor In Situ Apoptosis Detection Kit (R\&D Systems Inc., Minneapolis, MN, USA) following the manufacturer's instructions. Labelled cells were examined using fluorescence microscopy (Olympus, Tokyo, Japan) using a 405 488 nm filter [64]

\subsection{Gene Expression Analysis by Quantitative PCR ( $q P C R$ )}

Total RNAs from LN229 cells and astrocytes were extracted using RNeasy Mini Kit (Qiagen, Germantown, MD, USA) according to the manufacturer's instructions. Nanodrop (2000 series) (Thermo Fisher Scientific, Houston, TX, USA) was used for qualification and quantification of the RNA by reading the optical density (OD) at 260 and $280 \mathrm{~nm}$. Then cDNA was synthesized from RNA samples using High-Capacity cDNA Reverse Transcription Kit with RNase Inhibitor (Thermo Fisher Scientific, Houston, TX, USA) by following manufacturer's protocol. Quantitative PCR experiments were performed using StepOnePlus Real-Time PCR System (Thermo Fisher Scientific, Houston, TX, USA). Briefly, a reaction mixture of $20 \mu \mathrm{L}$, containing $10 \mu \mathrm{L}$ of PerfeCTa SYBR Green SuperMix Reaction Mixes (Quanta bio, Beverly, MA, USA), $300 \mathrm{nM}$ primers, and $50 \mathrm{ng}$ cDNA. Then, qPCR instrument's thermal cycling was programmed for 40 cycles at $95^{\circ} \mathrm{C}$ for $15 \mathrm{~s}$ and $53^{\circ} \mathrm{C}$ for $45 \mathrm{~s}$ after initial incubations at $95^{\circ} \mathrm{C}$ for $10 \mathrm{~min}$. GFAP, vimentin, Notch-1, and survivin expression was investigated with their own primer sequences of tested genes listed in Table $1[25,60,61]$. Target gene expression was normalized to GAPDH [36] levels in the same reaction using the $\Delta \Delta \mathrm{Ct}$ method.

Table 1. Primer sequences used in quantitative polymerase chain reaction (qPCR).

\begin{tabular}{ccc}
\hline Gene & Forward Primer & Reverse Primer \\
\hline GFAP & CCAAACTGGCTGACGTTTACC & TGGTTTCATCTTGGAGCTTCTG \\
Vimentin & CCC TCC GCA GCC ATG & ATG AGT GCT GCA CTG AGT GTG \\
Notch-1 & ATTTCACCGTGGGTGC & GTGTATCGGGCCCATCATGC \\
Survivin & CCGGGATCCATGGGTGCCCCGACGTTG & CGCGAATTCAGAGGCCTCAATCCATGG \\
GAPDH & CTCTGCTCCTCCTGTTCGAC & AAATGAGCCCCAGCCTTCTC \\
\hline
\end{tabular}

\subsection{Western Blot}

LN229 and astrocytes were co- or mono-cultured in the microwells, treated with TMZ and/or Bay 11-7082, and collected from the microwells. Then, they were washed with PBS protein, isolated, and lysed using RIPA lysis buffer (20-mM HEPES, pH 7.0, 200-mM NaCl, 1-mM EDTA, 1-mM EGTA, $1 \%$ Triton X-100, 5-mM sodium pyrophosphate, $80-\mathrm{mM} \beta$-glycerophosphate, $50-\mathrm{mM} \mathrm{NaF}, 0.1 \% \mathrm{SS}$ ) including freshly added protease inhibitor cocktail (Sigma-Aldrich, St. Louis, MO, USA) and phosphatase inhibitor cocktail 3 (Sigma-Aldrich, St. Louis, MO, USA). Cell lysates were incubated on ice for $30 \mathrm{~min}$ and centrifuged at $4{ }^{\circ} \mathrm{C}, 14,000 \mathrm{rpm}$ for $10 \mathrm{~min}$. Supernatants were collected and the concentration of protein was measured using Bradford Protein reagent (Bio-Rad, Hercules, 
CA, USA). Equal amounts of cell lysates were subjected to $4 \%-20 \%$ SDS-PAGE gels, transferred to a PVDF membrane (Thermo Fisher Scientific, Houston, TX, USA). Membranes were blocked with $5 \%$ milk (in 1× PBS-Tween20) for $30 \mathrm{~min}$, followed by primary antibody incubation overnight at $4{ }^{\circ} \mathrm{C}$. After three washes with PBS-Tween 20 ( 5 min each), membranes were incubated with secondary antibody (5\% milk in PBS-Tween20) for $1 \mathrm{~h}$. Protein bands were visualized using ECL Western blot detection system (Amersham Pharmacia Biotech). The data were normalized to $\beta$-actin. GFAP, vimentin (Santa Cruz, Dallas, TX, USA) Notch-1, $\beta$-Actin (Abcam, Cambridge, MA, USA), and survivin (Cell Signaling Technology, Danvers, MA, USA) antibodies were used at a concentration of 1:1000. Goat anti-Mouse IgG (H+L) Secondary Antibody (HRP) (Novus Biologicals, Centennial, CO, USA) was used at 1:2000 concentration.

\subsection{Statistical Analysis}

All results were from three independent experiments performed in triplicate. Statistical analysis was calculated using Student's t-test. Confidence intervals were set at $95 \%(p<0.05)$ and $99 \%(p<0.01)$. Error bars are mean \pm standard error.

Author Contributions: S.E.P., N.G.A., Y.M.A. and M.A. designed the experiment. S.E.P. conducted the experiments. S.E.P., N.G.A., Y.M.A. and M.A. analyzed and interpreted the data. S.E.P., N.G.A., Y.M.A., M.A. wrote and reviewed the manuscript. All authors have read and agreed to the published version of the manuscript.

Funding: This study is partially supported by a fund from the University of Houston. University of Houston (M.A.).

Acknowledgments: We would like to thank Lindsey McGill for editing the paper.

Conflicts of Interest: Authors S.E.P., N.G.A., Y.M.A., and M.A. declare no competing financial and/or non-financial interests.

\section{Abbreviations}

$\begin{array}{ll}\text { GBM } & \text { Glioblastoma multiforme } \\ \text { TMZ } & \text { Temozolomide } \\ \text { 3D } & \text { Three-dimensional } \\ \text { PEGDA } & \text { Poly (ethylene glycol) dimethyl acrylate } \\ \text { qPCR } & \text { Real-time polymerase chain reaction } \\ \text { MGMT } & \text { O }^{6} \text {-methylguanine-DNA methyltransferase } \\ \text { GFAP } & \text { Glial fibrillary acidic protein } \\ \text { CNS } & \text { Central nervous system } \\ \text { IF } & \text { Intermediate filament } \\ \text { EMT } & \text { Epithelial to mesenchymal transition } \\ \text { ECM } & \text { Extracellular matrix } \\ \text { TMSPMA } & \text { 3-(Trimethoxysilyl) propyl methacrylate } \\ \text { GJC } & \text { Gap junction communication } \\ \text { DMSO } & \text { Dimethylsulfoxide }\end{array}$

\section{References}

1. Kleihues, P.; Soylemezoglu, F.; Schäuble, B.; Scheithauer, B.W.; Burger, P.C. Histopathology, classification, and grading of gliomas. Glia 1995, 15, 211-221. [CrossRef] [PubMed]

2. Stupp, R.; Mason, W.P.; van den Bent, M.J.; Weller, M.; Fisher, B.; Taphoorn, M.J.B.; Belanger, K.; Brandes, A.A.; Marosi, C.; Bogdahn, U.; et al. Radiotherapy plus Concomitant and Adjuvant Temozolomide for Glioblastoma. N. Engl. J. Med. 2005, 352, 987-996. [CrossRef] [PubMed]

3. TAMIMI, A.F.; JUWEID, M. Epidemiology and Outcome of Glioblastoma. In Glioblastoma; Codon Publications: Singapore, 2017; pp. 143-153. ISBN 9780994438126.

4. Poon, C.C.; Sarkar, S.; Yong, V.W.; Kelly, J.J.P. Glioblastoma-associated microglia and macrophages: Targets for therapies to improve prognosis. Brain 2017, 140, 1548-1560. [CrossRef] [PubMed]

5. Li, G.; Qin, Z.; Chen, Z.; Xie, L.; Wang, R.; Zhao, H. Tumor Microenvironment in Treatment of Glioma. Open Med. (Warsaw, Poland) 2017, 12, 247-251. [CrossRef] 
6. Neyns, B.; Tosoni, A.; Hwu, W.-J.; Reardon, D.A. Dose-dense temozolomide regimens. Cancer 2010, 116, 2868-2877. [CrossRef]

7. Hegi, M.E.; Diserens, A.C.; Godard, S.; Dietrich, P.Y.; Regli, L.; Ostermann, S.; Otten, P.; Van Melle, G.; De Tribolet, N.; Stupp, R. Clinical Trial Substantiates the Predictive Value of O-6-Methylguanine-DNA Methyltransferase Promoter Methylation in Glioblastoma Patients Treated with Temozolomide. Clin. Cancer Res. 2004, 10, 1871-1874. [CrossRef]

8. Wang, X.; Jia, L.; Jin, X.; Liu, Q.; Cao, W.; Gao, X.; Yang, M.; Sun, B. NF-kB inhibitor reverses temozolomide resistance in human glioma TR/U251 cells. Oncol. Lett. 2015, 9, 2586-2590. [CrossRef]

9. Kumar, A.; Takada, Y.; Boriek, A.M.; Aggarwal, B.B. Nuclear factor-kB: Its role in health and disease. J. Mol. Med. 2004, 82, 434-448. [CrossRef]

10. Xia, H.; Avci, N.G.; Akay, Y.; Esquenazi, Y.; Schmitt, L.H.; Tandon, N.; Zhu, J.-J.; Akay, M. Temozolomide in Combination With NF-kB Inhibitor Significantly Disrupts the Glioblastoma Multiforme Spheroid Formation. IEEE Open J. Eng. Med. Biol. 2019, 1, 9-16. [CrossRef]

11. Hanahan, D.; Weinberg, R.A. Hallmarks of cancer: The next generation. Cell 2011, 144, 646-674. [CrossRef]

12. Sofroniew, M.V. Reactive astrocytes in neural repair and protection. Neuroscientist 2005, 11, $400-407$. [CrossRef] [PubMed]

13. Tezel, G.; Hernandez, M.R.; Wax, M.B. In vitro evaluation of reactive astrocyte migration, a component of tissue remodeling in glaucomatous optic nerve head. Glia 2001, 34, 178-189. [CrossRef] [PubMed]

14. Khakh, B.S.; Sofroniew, M.V. Diversity of astrocyte functions and phenotypes in neural circuits. Nat. Neurosci. 2015, 18, 942-952. [CrossRef] [PubMed]

15. Boccazzi, M.; Ceruti, S. Where do you come from and what are you going to become, reactive astrocyte? Stem Cell Investig. 2016, 3, 15. [CrossRef] [PubMed]

16. Charles, N.A.; Holland, E.C.; Gilbertson, R.; Glass, R.; Kettenmann, H. The brain tumor microenvironment. Glia 2012, 60, 502-514. [CrossRef]

17. Henrik Heiland, D.; Ravi, V.M.; Behringer, S.P.; Frenking, J.H.; Wurm, J.; Joseph, K.; Garrelfs, N.W.C.; Strähle, J.; Heynckes, S.; Grauvogel, J.; et al. Tumor-associated reactive astrocytes aid the evolution of immunosuppressive environment in glioblastoma. Nat. Commun. 2019, 10,1-12. [CrossRef]

18. Gagliano, N.; Costa, F.; Cossetti, C.; Pettinari, L.; Bassi, R.; Chiriva-Internati, M.; Cobos, E.; Gioia, M.; Pluchino, S. Glioma-astrocyte interaction modifies the astrocyte phenotype in a co-culture experimental model. Oncol. Rep. 2009, 22, 1349-1356. [CrossRef]

19. Shiras, A.; Bhosale, A.; Shepal, V.; Shukla, R.; Baburao, V.S.; Prabhakara, K.; Shastry, P. A Unique Model. System for Tumor Progression in GBM Comprising Two Developed Human Neuro-Epithelial Cell Lines with Differential Transforming Potential and Coexpressing Neuronal and Glial Markers 1. Neoplasia 2003, 5, 520-532. [CrossRef]

20. Barbero, S.; Bajetto, A.; Bonavia, R.; Porcile, C.; Piccioli, P.; Pirani, P.; Ravetti, J.L.; Zona, G.; Spaziante, R.; Florio, T.; et al. Expression of the Chemokine Receptor CXCR4 and Its Ligand Stromal Cell-Derived Factor 1 in Human Brain Tumors and Their Involvement in Glial Proliferation in Vitro. Ann. N. Y. Acad. Sci. 2002, 973, 60-69. [CrossRef]

21. Somasundaram, K.; Reddy, S.P.; Vinnakota, K.; Britto, R.; Subbarayan, M.; Nambiar, S.; Hebbar, A.; Samuel, C.; Shetty, M.; Sreepathi, H.K.; et al. Upregulation of ASCL1 and inhibition of Notch signaling pathway characterize progressive astrocytoma. Oncogene 2005, 24, 7073-7083. [CrossRef]

22. Guruharsha, K.G.; Kankel, M.W.; Artavanis-Tsakonas, S. The Notch signalling system: Recent insights into the complexity of a conserved pathway. Nat. Rev. Genet. 2012, 13, 654-666. [CrossRef]

23. Verhaak, R.G.W.; Hoadley, K.A.; Purdom, E.; Wang, V.; Qi, Y.; Wilkerson, M.D.; Miller, C.R.; Ding, L.; Golub, T.; Mesirov, J.P.; et al. Integrated Genomic Analysis Identifies Clinically Relevant Subtypes of Glioblastoma Characterized by Abnormalities in PDGFRA, IDH1, EGFR, and NF1. Cancer Cell 2010, 17, 98-110. [CrossRef]

24. Suzuki, A.; Ito, T.; Kawano, H.; Hayashida, M.; Hayasaki, Y.; Tsutomi, Y.; Akahane, K.; Nakano, T.; Miura, M.; Shiraki, K. Survivin initiates procaspase 3/p21 complex formation as a result of interaction with Cdk4 to resist Fas-mediated cell death. Oncogene 2000, 19, 1346-1353. [CrossRef] [PubMed] 
25. Suzuki, A.; Hayashida, M.; Ito, T.; Kawano, H.; Nakano, T.; Miura, M.; Akahane, K.; Shiraki, K. Survivin initiates cell cycle entry by the competitive interaction with Cdk4/p16(INK4a) and Cdk2/Cyclin E complex activation. Oncogene 2000, 19, 3225-3234. [CrossRef] [PubMed]

26. Chakravarti, A.; Zhai, G.G.; Zhang, M.; Malhotra, R.; Latham, D.E.; Delaney, M.A.; Robe, P.; Nestler, U.; Song, Q.; Loeffler, J. Survivin enhances radiation resistance in primary human glioblastoma cells via caspase-independent mechanisms. Oncogene 2004, 23, 7494-7506. [CrossRef]

27. Luca, A.C.; Mersch, S.; Deenen, R.; Schmidt, S.; Messner, I.; Schäfer, K.-L.; Baldus, S.E.; Huckenbeck, W.; Piekorz, R.P.; Knoefel, W.T.; et al. Impact of the 3D Microenvironment on Phenotype, Gene Expression, and EGFR Inhibition of Colorectal Cancer Cell Lines. PLoS ONE 2013, 8, e59689. [CrossRef] [PubMed]

28. Shin, C.S.; Kwak, B.; Han, B.; Park, K.; Panitch, A. 3D cancer tumor models for evaluating chemotherapeutic efficacy. Biomater. Cancer Ther. 2013, 445-460. [CrossRef]

29. Sigrid, A. Langhans Three-Dimensional in Vitro Cell Culture Models in Drug Discovery and Drug Repositioning. Front. Pharmacol. 2018, 9, 6. [CrossRef]

30. Khademhosseini, A.; Langer, R.; Borenstein, J.; Vacanti, J.P. Microscale Technologies for Tissue Engineering and Biology. Source 2006, 103, 2480-2487. [CrossRef]

31. Mohr, J.C.; De Pablo, J.J.; Palecek, S.P. 3-D microwell culture of human embryonic stem cells. Biomaterials 2006, 27, 6032-6042. [CrossRef]

32. Karp, J.M.; Yeo, Y.; Geng, W.; Cannizarro, C.; Yan, K.; Kohane, D.S.; Vunjak-Novakovic, G.; Langer, R.S.; Radisic, M. A photolithographic method to create cellular micropatterns. Biomaterials 2006, 27, 4755-4764. [CrossRef] [PubMed]

33. Fan, Y.; Avci, N.G.; Nguyen, D.T.; Dragomir, A.; Akay, Y.M.; Akay, M. Engineering a High-Throughput 3-D In Vitro Glioblastoma Model. IEEE J. Transl. Eng. Health Med. 2015, 3, 4300108. [CrossRef] [PubMed]

34. Gill, B.J.; Gibbons, D.L.; Roudsari, L.C.; Saik, J.E.; Rizvi, Z.H.; Roybal, J.D.; Kurie, J.M.; West, J.L. A synthetic matrix with independently tunable biochemistry and mechanical properties to study epithelial morphogenesis and EMT in a lung adenocarcinoma model. Cancer Res. 2012, 72, 6013-6023. [CrossRef] [PubMed]

35. Nguyen, D.T.; Fan, Y.; Akay, Y.M.; Akay, M. TNP-470 reduces glioblastoma angiogenesis in three dimensional Gel MA microwell platform. IEEE Trans. Nanobiosci. 2016, 15, 683-688. [CrossRef] [PubMed]

36. Avci, N.G.; Fan, Y.; Dragomir, A.; Akay, Y.M.; Akay, M. Investigating the Influence of HUVECs in the Formation of Glioblastoma Spheroids in High-Throughput Three-Dimensional Microwells. IEEE Trans. Nanobiosci. 2015, 14, 790-796. [CrossRef] [PubMed]

37. Sugita, H.; Uchida, T.; Kato, S.; Suda, K.; Miyaji, M. Photosensitive anti-biofouling polycarboxymethylbetaine coating: Polymerization, photolithography, and cell aggregation along the pattern geometry. Microelectron. Eng. 2018, 189, 11-17. [CrossRef]

38. Khademhosseini, A.; Langer, R. Microgengineered hydrogels for tissue engineering. Biomaterials 2007, 28, 5087-5092. [CrossRef]

39. Sant, S.; Johnston, P.A.; Carragher, N.O.; Lee, J.A. The production of 3D tumor spheroids for cancer drug discovery. Drug Discov. Today Technol. 2017, 23, 27-36. [CrossRef]

40. Agnihotri, S.; Gajadhar, A.S.; Ternamian, C.; Gorlia, T.; Diefes, K.L.; Mischel, P.S.; Kelly, J.; McGown, G.; Thorncroft, M.; Carlson, B.L.; et al. Alkylpurine - DNA - N-glycosylase confers resistance to temozolomide in xenograft models of glioblastoma multiforme and is associated with poor survival in patients. J. Clin. Investig. 2012, 122, 253-266. [CrossRef]

41. Montaldi, A.P.; Godoy, P.R.D.V.; Sakamoto-Hojo, E.T. APE1/REF-1 down-regulation enhances the cytotoxic effects of temozolomide in a resistant glioblastoma cell line. Mutat. Res. Genet. Toxicol. Environ. Mutagen. 2015, 793, 19-29. [CrossRef]

42. Marchetti, D.; Li, J.; Shen, R. Astrocytes Contribute to the Brain-metastatic Specificity of Melanoma Cells by Producing Heparanase. Cancer Res. 2000, 60.

43. Haydon, P.G.; Blendy, J.; Moss, S.J.; Rob Jackson, F. Astrocytic control of synaptic transmission and plasticity: A target for drugs of abuse? Neuropharmacology 2009, 56, 83-90. [CrossRef]

44. Dresselhaus, E.C.; Meffert, M.K. Cellular specificity of NF-кB function in the nervous system. Front. Immunol. 2019, 10, 1043. [CrossRef] [PubMed] 
45. Lin, S.T.; Wang, Y.; Xue, Y.; Feng, D.C.; Xu, Y.; Xu, L.Y. Tetrandrine suppresses LPS-induced astrocyte activation via modulating IKKs-IкB $\alpha-\mathrm{NF}-\kappa \mathrm{B}$ signaling pathway. Mol. Cell. Biochem. 2008, 315, 41-49. [CrossRef] [PubMed]

46. Brambilla, R.; Bracchi-Ricard, V.; Hu, W.H.; Frydel, B.; Bramwell, A.; Karmally, S.; Green, E.J.; Bethea, J.R. Inhibition of astroglial nuclear factor $\mathrm{kB}$ reduces inflammation and improves functional recovery after spinal cord injury. J. Exp. Med. 2005, 202, 145-156. [CrossRef]

47. van de Waterbeemd, H.; Gifford, E. ADMET in silico modelling: Towards prediction paradise? Nat. Rev. Drug Discov. 2003, 2, 192-204. [CrossRef]

48. Lee, M.Y.; Kumar, R.A.; Sukumaran, S.M.; Hogg, M.G.; Clark, D.S.; Dordick, J.S. Three-dimensional cellular microarray for high-throughput toxicology assays. Proc. Natl. Acad. Sci. USA 2008, 105, 59-63. [CrossRef]

49. Gomez-Roman, N.; Stevenson, K.; Gilmour, L.; Hamilton, G.; Chalmers, A.J. A novel 3D human glioblastoma cell culture system for modeling drug and radiation responses. Neuro. Oncol. 2017, 19, 229-241. [CrossRef]

50. Musah-Eroje, A.; Watson, S. A novel 3D in vitro model of glioblastoma reveals resistance to temozolomide which was potentiated by hypoxia. J. Neurooncol. 2019, 142, 231-240. [CrossRef]

51. Dahl, D.; Rueger, D.C.; Bignami, A. Vimentin, the 57000 molecular weight protein of fibroblast filaments, is the major cytoskeletal component in immature glia. Eur. J. Cell Biol. 1981, 24, 191-196.

52. Boyne, L.J.; Fischer, I.; Shea, T.B. Role of vimentin in early stages of neuritogenesis in cultured hippocampal neurons. Int. J. Dev. Neurosci. 1996, 14, 739-748. [CrossRef]

53. Yang, N.; Yan, T.; Zhu, H.; Liang, X.; Leiss, L.; Sakariassen, Ø.; Skaftnesmo, K.O.; Huang, B.; Costea, D.E.; $\mathrm{Li}, \mathrm{X}$; et al. A co-culture model with brain tumor-specific bioluminescence demonstrates astrocyte-induced drug resistance in glioblastoma. J. Transl. Med. 2014, 12, 1-9. [CrossRef] [PubMed]

54. Lin, Q.; Liu, Z.; Ling, F.; Xu, G. Astrocytes protect glioma cells from chemotherapy and upregulate survival genes via gap junctional communication. Mol. Med. Rep. 2016, 13, 1329-1335. [CrossRef] [PubMed]

55. Burda, J.E.; Bernstein, A.M.; Sofroniew, M.V. Astrocyte roles in traumatic brain injury. Exp. Neurol. 2016, 275, 305-315. [CrossRef] [PubMed]

56. Singh, S.K.; Hawkins, C.; Clarke, I.D.; Squire, J.A.; Bayani, J.; Hide, T.; Henkelman, R.M.; Cusimano, M.D.; Dirks, P.B. Identification of human brain tumour initiating cells. Nature 2004, 432, 396-401. [CrossRef]

57. Ambrosini, G.; Adida, C.; Altieri, D.C. A novel anti-apoptosis gene, survivin, expressed in cancer and lymphoma. Nat. Med. 1997, 3, 917-921. [CrossRef]

58. Garner, J.M.; Fan, M.; Yang, C.H.; Du, Z.; Sims, M.; Davidoff, A.M.; Pfeffer, L.M. Constitutive activation of signal transducer and activator of transcription 3 (STAT3) and nuclear factor $\mathrm{kb}$ signaling in glioblastoma cancer stem cells regulates the notch pathway. J. Biol. Chem. 2013, 288, 26167-26176. [CrossRef]

59. Guindalini, R.S.C.; Mathias Machado, M.C.; Garicochea, B. Monitoring survivin expression in cancer: Implications for prognosis and therapy. Mol. Diagnosis Ther. 2013, 17, 331-342. [CrossRef]

60. Zhou, R.; Skalli, O. TGF- $\alpha$ Differentially Regulates GFAP, Vimentin, and Nestin Gene Expression in U-373 MG Glioblastoma Cells: Correlation with Cell Shape and Motility. Exp. Cell Res. 2000, 254, 269-278. [CrossRef]

61. Angulo-Rojo, C.; Manning-Cela, R.; Aguirre, A.; Ortega, A.; López-Bayghen, E. Involvement of the Notch pathway in terminal astrocytic differentiation: Role of PKA. ASN Neuro 2013, 5, AN20130023. [CrossRef]

62. Chakravarti, A.; Noll, E.; Black, P.M.; Finkelstein, D.F.; Finkelstein, D.M.; Dyson, N.J.; Loeffler, J.S. Quantitatively Determined Survivin Expression Levels Are of Prognostic Value in Human Gliomas. J. Clin. Oncol. 2002, 20, 1063-1068. [CrossRef] [PubMed]

63. Lebelt, A.; Rutkowski, R.; Och, W.; Jaczun, K.; Dziemiańczyk-Pakieła, D.; Milewski, R.; Mariak, Z.; Reszeć, J. Survivin, caspase-3 and MIB-1 expression in astrocytic tumors of various grades. Adv. Med. Sci. 2016, 61, 237-243. [CrossRef] [PubMed]

64. Avci, N.G.; Ebrahimzadeh-Pustchi, S.; Akay, Y.M.; Esquenazi, Y.; Tandon, N.; Zhu, J.-J.; Akay, M. NF-kB inhibitor with Temozolomide results in significant apoptosis in glioblastoma via the NF- $\mathrm{B}(\mathrm{p} 65)$ and actin cytoskeleton regulatory pathways. Sci. Rep. 2020, 10, 1-14. [CrossRef] [PubMed]

65. Adamski, V.; Hempelmann, A.; Flüh, C.; Lucius, R.; Synowitz, M.; Hattermann, K.; Held-Feindt, J. Dormant glioblastoma cells acquire stem cell characteristics and are differentially affected by Temozolomide and AT101 treatment. Oncotarget 2017, 8, 108064-108078. [CrossRef] [PubMed] 
66. Wang, L.; Liu, Z.; Balivada, S.; Shrestha, T.; Bossmann, S.; Pyle, M.; Pappan, L.; Shi, J.; Troyer, D. Interleukin-1 $\beta$ and transforming growth factor- cooperate to induce neurosphere formation and increase tumorigenicity of adherent LN-229 glioma cells. Stem Cell Res. Ther. 2012, 3, 1-16. [CrossRef] [PubMed]

67. Dirkse, A.; Golebiewska, A.; Buder, T.; Nazarov, P.V.; Muller, A.; Poovathingal, S.; Brons, N.H.C.; Leite, S.; Sauvageot, N.; Sarkisjan, D.; et al. Stem cell-associated heterogeneity in Glioblastoma results from intrinsic tumor plasticity shaped by the microenvironment. Nat. Commun. 2019, 10, 1-16. [CrossRef]

(C) 2020 by the authors. Licensee MDPI, Basel, Switzerland. This article is an open access article distributed under the terms and conditions of the Creative Commons Attribution (CC BY) license (http://creativecommons.org/licenses/by/4.0/). 